\title{
病院レセプトデータを用いた降圧薬の処方動向に関する調査
}

\author{
佐藤倫広 ${ }^{* 1,2}$, 黒澤桂子 ${ }^{3}$, 小原 拓 $^{3,4}$, 松浦正樹 ${ }^{3}$, 井上隆輔 ${ }^{5}$ \\ 高橋信行 $^{6}$, 佐藤 博 $^{6}$, 村井ユリ子 ${ }^{3,7}$, 眞野成康 ${ }^{3}$ \\ 東北医科薬科大学医学部衛生学・公衆衛生学教室 ${ }^{1}$, 東北大学薬学部 ${ }^{2}$, 東北大学病院薬剤部 ${ }^{3}$ \\ 東北大学東北メディカル・メガバンク機構予防医学・疫学部門 ${ }^{4}$, 東北大学病院メディカルITセンター ${ }^{5}$ \\ 東北大学大学院薬学研究科臨床薬学分野, 東北大学大学院薬学研究科医療薬学教育研究セン夕ー ${ }^{7}$

\section{Trends in Antihypertensive Drug Prescriptions Based on Claims Data in a Japanese Hospital}

\begin{abstract}
Michihiro Satoh ${ }^{1,2 *}$, Keiko Kurosawa ${ }^{3}$, Taku Obara ${ }^{3.4}$, Masaki Matsuura ${ }^{3}$, Ryusuke Inoue, Nobuyuki Takahashi, Hiroshi Sato ${ }^{6}$, Yuriko Murai ${ }^{3.7}$ and Nariyasu Mano ${ }^{3}$

Division of Public Health, Hygiene and Epidemiology, Faculty of Medicine, Tohoku Medical and Pharmaceutical University ${ }^{1}$, Faculty of Pharmaceutical Sciences, Tohoku University ${ }^{2}$, Department of Pharmaceutical Sciences, Tohoku University Hospital ${ }^{3}$,

Department of Preventive Medicine and Epidemiology, Tohoku Medical Megabank Organization, Tohoku University ${ }^{4}$, Medical Information Technology Center, Tohoku University Hospital ${ }^{5}$,

Department of Clinical Pharmacology and Therapeutics, Tohoku University Graduate School of Pharmaceutical Sciences ${ }^{6}$, Pharmacy Education and Research Center, Tohoku University Graduate School of Pharmaceutical Sciences ${ }^{7}$

$$
\left[\begin{array}{l}
\text { Received June 24, } 2016 \\
\text { Accepted November 15, } 2016
\end{array}\right]
$$

Details regarding trends in the prescription rates of antihypertensive drugs after 2011 are unclear. Therefore, we compared the prescription rates of antihypertensive drugs in 2009 with those in 2014 using claim records. Data were extracted from claims data provided from April-July 2009 and from April-July 2014 in Tohoku University Hospital, Sendai, Japan. Prescription rates were presented as the percentage of patients who were prescribed each drug. We compared the prescription rates in $2009(\mathrm{n}=3,954$, mean age 63.8 years, men 53.4\%) with those in $2014(\mathrm{n}=5,196$, mean age 63.3 years, men $52.9 \%$ ). The two most prescribed classes of antihypertensive drugs were angiotensin II receptor blockers and calcium channel blockers in both years $(\geq 60 \%)$. No significant changes in the prescription rates for these two classes were observed between 2009 and 2014. The prescription rate for aldosterone blockers and $\alpha \beta-$ blockers increased from $12.6 \%$ and $8.4 \%$ in 2009 to $16.9 \%$ and $13.5 \%$ in $2014(P<0.0001)$, respectively. In contrast, the prescription rate for angiotensin converting enzyme inhibitors and $\alpha$-blockers decreased from $23.5 \%$ and $10.4 \%$ in 2009 to $15.6 \%$ and $7.7 \%$ in $2014(P<0.0001)$, respectively. The prescription rates for thiazide diuretics, non-thiazide diuretics other than aldosterone blockers, $\beta$-blockers, and other classes of antihypertensive did not differ significantly between 2009 and 2014. The prescription rates of antihypertensive drugs have changed based on new evidence regarding the drugs' mechanisms of action on hypertension or their adverse effects.
\end{abstract}

Key words — prescription rate, antihypertensive drugs, pharmacoepidemiology, hypertension

\footnotetext{
*\%981-8558 宮城県仙台市青葉区小松島4-4-1
} 


\section{緒言}

高血圧は, 日本人の死因第 2 位である心疾患と 第 4 位である脳血管疾患の最大のリスク要因であ り，高血圧により年間約 10 万人が死亡していると 推計されている. ${ }^{1)}$ 特に脳血管疾患は, 要介護とな る要因の第一位であり，適切な降圧治療は健康寿 命の延長のためにも極めて重要である. ${ }^{1)}$ National Integrated Project for Prospective Observation of Noncommunicable Disease And its Trends in the Aged （NIPPON DATA）のデータでは，60６9歳の高 血圧有病者に打ける降圧治療率は, 1980 年の $36.7 \%$ から 2010 年の $51.6 \%$ へ上昇している. ${ }^{2}$ 一方，治療者に打ける降圧目標達成率は，2010 年で $50 \%$ に満たない状況であり，より厳格な高 血圧治療が一般医家に対して求められている. ${ }^{1)}$

日本高血圧学会が定める高血圧治療（Japanese Society of Hypertension: JSH）ガイドラインには, 推奨される降圧治療および降圧目標が詳細に記載 されている.JSH ガイドラインは，高齢化やメタ ボリック症候群の増加などの社会状況の変遷，ま たは蓄積されたエビデンスなどに対応するため, およそ 5 年毎にその内容が更新されており, 近年 では 2014 年 4 月に JSH ガイドライン 2009 から 2014 へ改定されている。JSH ガイドライン 2014 での大きな改定点の 1 つに，降圧治療の第一選択 薬であったカルシウム拮抗薬, アンジオテンシン II 受容体拮抗薬（angiotensin II receptor blocker: ARBs），アンジオテンシン変換酵素（angiotensin converting enzyme: ACE）阻害薬， $\beta$ 遮断薬，およ び利尿薬から， $\beta$ 遮断薬が除外されたことが挙げ られる. ${ }^{1}$ この理由として, $\beta$ 遮断薬単剂あるいは ほかの降圧薬との併用療法を用いた臨床試験で, $\beta$ 遮断薬の糖尿病惹起の副作用, ${ }^{3,4}$ 臓器障害や心 血管疾患の予防効果が他薬に劣ることなどが示さ れたためである.5.6) これら JSH ガイドライン 2014 への改定も踏まえて, 降圧薬の処方動向が変化し ている可能性があるが，本邦における降圧薬の処 方動向は 2011 年までしか捉えられていない. ${ }^{7.8)}$

近年, 各病院において医療記録の電子化の推進 やデー夕の蓄積がなされており，多くの医療機関 が長期間にわたる過去の診療情報明細書（レセプ
ト）デー夕を利用可能な状況にある。過去に我々 は，日本医療データセンターが有するレセプト データを用いて, 広汎性発達障害児に対する向精 神薬の処方割合が増加している可能性を示してい

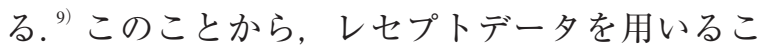
とで, 高血圧患者に扔ける近年の降圧薬処方動向 も検討可能と考えられる.

本研究の目的は, 当院を受診した高血圧外来患 者のレセプトまたは診療支援システムデー夕を用い て，JSH ガイドライン改定時点である，2009年と 2014 年の降圧薬の処方割合を比較することである.

\section{方 法}

\section{1. 研究デザイン}

本研究は, 2014 年 12 月末までに当院において, レセプトまたは診療支援システムで収集された情 報を基に，後ろ向き調査として実施された.

JSH ガイドラインの改訂版が上梓された 2009 年 と 2014 年の処方動向の比較を行った. 血圧の季節 変動に伴い, 降圧薬の処方は変動するため, 対象 期間を各年の 4 月 1 日〜 7 月 31 日と同一の 4 カ月 間に限定した。本研究は, 『人を対象とする医学系 研究に関する倫理指針』に準拠し, 東北大学大学 院医学系研究科の倫理審査委員会の承認 (承認番 号 2015-1-742）を得て実施されている。 また，連結 不可能匿名化情報としてデータを抽出しているた め, 対象者からの同意は取得されていないが，才 プトアウト方式として研究に関する情報公開を行 い，本人の研究参加拒否に対応できる体制とした。

\section{2. 対象者}

本研究の対象者は, 当院の外来で降圧薬を処方 された 35 歳以上の高血圧症患者である. 対象者選 定のフローチャートを Fig 1 に示す，それぞれの年 にレセプトで “高血圧”の用語を含む傷病名が付 与された対象者 2009 年：10,848 名および 2014 年： 11,484 名を抽出し, 調查対象期間より前に, 国際 疾病分類第 10 版（ICD-10; International Statistical Classification of Diseases 10th Revision）コードで 『I10: 本態性（原発性 <一次性 > ）高血圧（症）』 に分類される傷病名を一度でも有した高血圧症患 


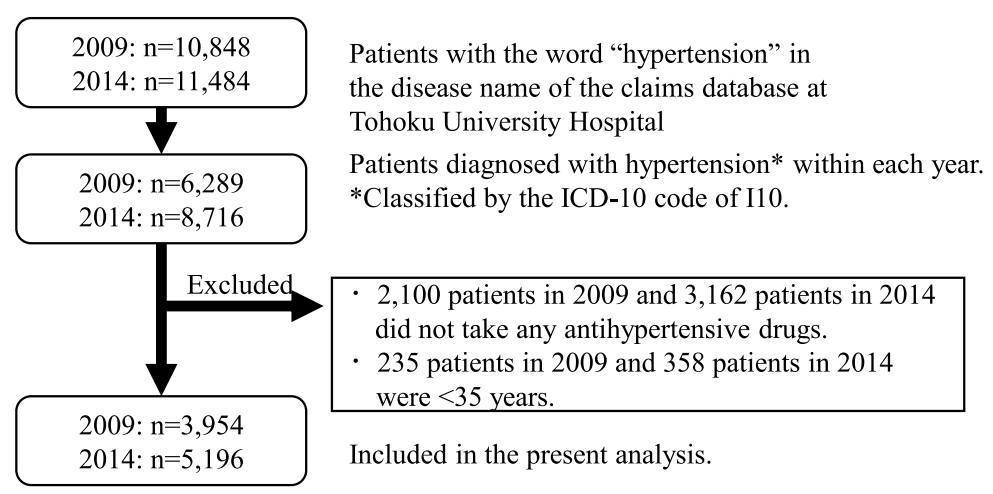

Fig 1 Flow chart of study participants

ICD-10: International Classification of Diseases, version 10 codes.

者 2009 年：6,289 名および 2014 年：8,716 名を対象 者とした，そのうち，対象期間内に外来で降圧薬が 処方されなかった者（2009年：2,100 名および 2014 年：3,162 名）および 35 歳未満の者（2009 年：235 名および 2014 年：358名)を除外した 2009 年：3,954 名および 2014 年：5,196 名を解析対象者とした。

\section{3. デー夕収集}

当院の診療支援システムから抽出した解析対象 者の処方薬情報を基に，薬効分類別でカルシウム 拮抗薬，ARBs， $\alpha \beta$ 遮断薬，アルドステロン拮抗 薬, ACE 阻害薬, $\beta$ 遮断薬, 非サイアザイド系利 尿薬, サイアザイド系（類似）利尿薬， $\alpha$ 遮断薬， 直接的レニン阻害薬，およびその他の降圧薬（血 管拡張薬， $\alpha_{2}$ 遮断薬）を降圧薬として定義した. これは，JSH ガイドライン 2014 で示される各種降 圧薬の分類に加え, ${ }^{1}$ 利尿薬を非サイアザイド系と サイアザイド系 (類似), $\alpha \beta$ ・ $\beta$ 遮断薬を $\alpha \beta$ 遮断 薬と $\beta$ 遮断薬に細分類化した定義である.ただし， 本邦において高血圧症の適応はないビソプロロー ル錠 $0.625 \mathrm{mg}$, カルベジロール錠 $2.5 \mathrm{mg}$, および ベラパミル錠 $40 \mathrm{mg}$ は解析から除外した. 配合剤 は，配合されている成分の薬効分類毎に分けて集 計した。当院の院外処方箋発行率は 2006 年度以 降 90\%を常に超えている（http://www.pharm.hosp. tohoku.ac.jp/Duties/jisseki.html, 2016 年 9 月 28 日).

\section{4. その他疾患のデータ収集方法と定義}

調查対象期間より前に付与された傷病名を基に 既往歴を定義した。傷病名に“心筋梗塞”, “狭心
症”，または“冠動脈閉塞”が含まれる場合は冠 動脈疾患, “心不全”が含まれる場合は心不全, “高 脂血症”，“脂質代謝異常”，または“脂質異常” が含まれる場合は脂質代謝異常症, “糖尿病” が 含まれる場合は糖尿病, “脳出血”または“脳梗塞” が含まれる場合は脳卒中, “腎障害”または“腎 不全”が含まれる場合は腎障害の既往歴有りと定 義した。保険傷病名の影響を最小限とするため “疑”が含まれる傷病名を対象から除外した。

\section{5. 統計解析}

薬効分類別および一般名別の処方割合 $(=$ 処方 された患者数 / 各年の解析対象者数 $\times 100[\%]$ ) を算出した．観察期間内に， 1 度でも対象の降圧 薬が処方された場合は，処方ありと定義した。 2009 年と 2014 年の患者特性㧍よび降圧薬の処方 割合の差異の検定には Student の $t$ 検定および $\chi$ 二乗検定を用いた．2009年と 2014 年で重複する 患者における検定には, 対応のある検定としてマ クネマー検定を $\chi$ 二乗検定の代わりに用いた。患 者特性の年間の差異が, 処方割合の変化の交絡要 因となる可能性があることから, 各種降圧薬の処 方有無（目的変数）と 2014 年を $1 / 2009$ 年を 0 と した変数（説明変数）の関連を, 年齢, 性別, 糖 尿病既往, 脂質代謝異常症既往, 心不全既往, 冠 動脈疾患既往, 脳卒中既往, 腎障害既往, および 降圧薬 3 鼡以上服用を調整した多重ロジスティッ ク回帰分析で改めて解析した. 統計学的有意水準 を $P<0.05$ とした。連続变数を平均土標準偏差と して示した。統計解析には SAS ver 9.4 を用いた。 


\section{結果}

\section{1. 患者特性}

2009 年および 2014 年における対象者の平均年

齢はそれぞれ，63.8 \pm 12.4 歳および $63.3 \pm 12.9$

歳 $(P=0.07)$, 男性の割合は $53.4 \%$ および $52.9 \%$

（P=0.6）であった（Table 1)。2014 年の患者は
2009 年の患者に比べて心不全および腎障害が有 意に高率であり, 脂質代謝異常症および脳卒中が 有意に低率であった $(P \leq 0.03$, Table 1).

\section{2. 各降圧薬の処方推移}

2009 年と 2014 年の降圧薬の処方推移を Fig 2 に示す．高率に処方されていた降圧薬は，カルシ

Table 1 Patients' characteristics

\begin{tabular}{lccc}
\hline \hline & \multicolumn{2}{c}{ Year } & \multirow{2}{*}{$P$} \\
\cline { 2 - 3 } & 2009 & 2014 & \\
\hline Age, years & $(\mathrm{n}=3,954)$ & $(\mathrm{n}=5,196)$ & \\
Men, \% & $63.8 \pm 12.4$ & $63.3 \pm 12.9$ & 0.07 \\
Diabetes, \% & 53.4 & 52.9 & 0.6 \\
Dyslipidemia, \% & 67.3 & 65.6 & 0.09 \\
Heart failure, \% & 46.9 & 44.6 & 0.03 \\
Ischemic heart disease, \% & 42.9 & 46.3 & 0.001 \\
Cerebrovascular disease, \% & 32.0 & 33.2 & 0.2 \\
Kidney disease, \% & 22.0 & 17.2 & $<0.0001$ \\
No. of antihypertensive drugs, \% & 11.7 & 13.5 & 0.008 \\
$\quad 1$ & 36.3 & & 0.2 \\
2 & 33.1 & 34.8 & \\
$\geq 3$ & 30.7 & 32.9 & \\
\hline
\end{tabular}

Data are mean \pm standard deviation or percentage. We compared means and proportions using Student's $t$-test and the chi-square test for univariate analysis, respectively.

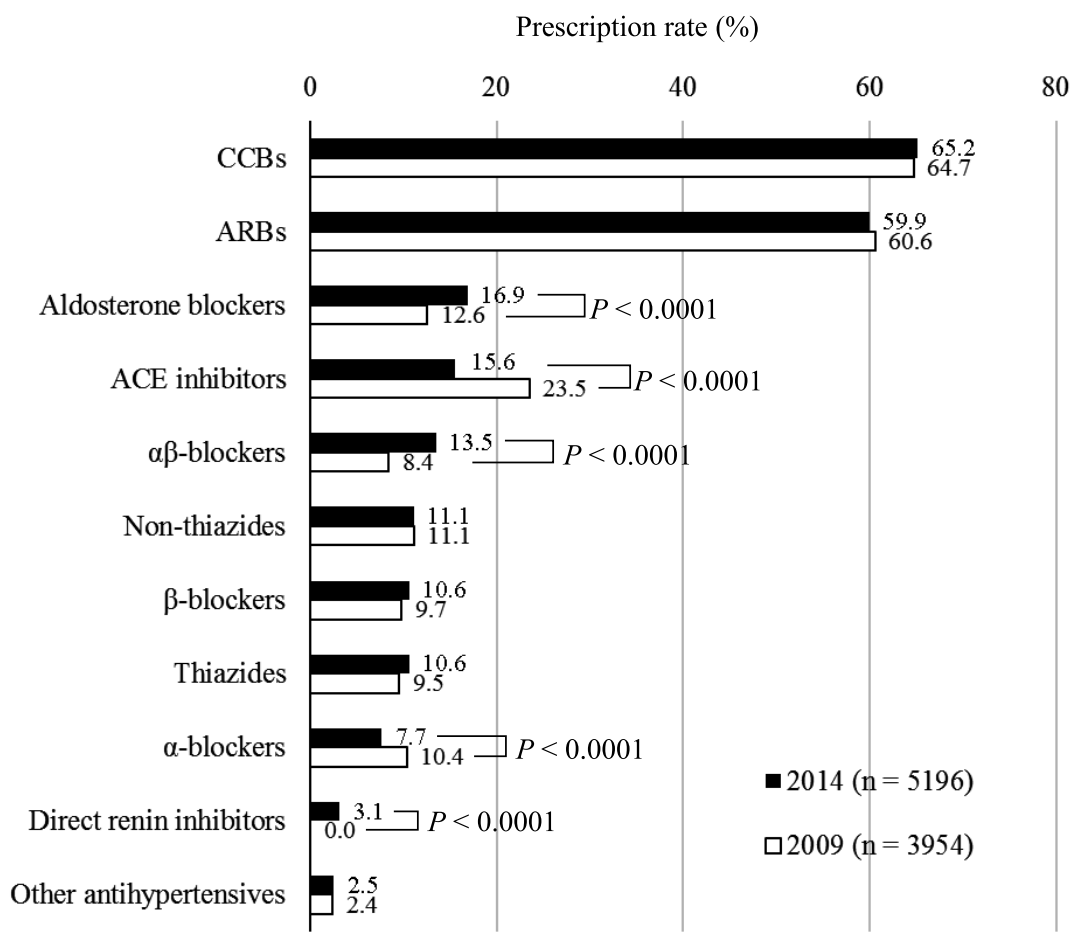

Fig 2 Prescription rates for each year

Thiazides include indapamide, which is a thiazide-related diuretic. Non-thiazides did not include aldosterone blockers. ACE: angiotensin converting enzyme, ARBs: angiotensin II receptor blockers, CCBs: calcium channel blockers. The chi-square test was used for analyses. 
Table 2 Prescription rates according to year in unpaired and paired patients

\begin{tabular}{|c|c|c|c|c|c|c|}
\hline \multirow{3}{*}{$\begin{array}{l}\text { Prescription rates, \% } \\
\text { Antihypertensive drugs }\end{array}$} & \multirow{2}{*}{\multicolumn{2}{|c|}{$\begin{array}{c}\text { Unpaired patients } \\
\text { Year }\end{array}$}} & \multirow[b]{3}{*}{$\begin{array}{c}\text { Chi-square test } \\
P\end{array}$} & \multirow{2}{*}{\multicolumn{2}{|c|}{$\begin{array}{c}\text { Paired patients } \\
\text { Year }\end{array}$}} & \multirow[b]{3}{*}{$\begin{array}{c}\text { McNemar test } \\
P\end{array}$} \\
\hline & & & & & & \\
\hline & $\begin{array}{c}2009 \\
(\mathrm{n}=1,934)\end{array}$ & $\begin{array}{c}2014 \\
(\mathrm{n}=3,176)\end{array}$ & & $\begin{array}{c}2009 \\
(\mathrm{n}=2,020)\end{array}$ & $\begin{array}{c}2014 \\
(\mathrm{n}=2,020)\end{array}$ & \\
\hline CCBs & 62.5 & 62.7 & 0.9 & 66.8 & 69.1 & 0.01 \\
\hline $\mathrm{ARBs}$ & 58.0 & 56.0 & 0.2 & 63.1 & 66.2 & 0.0002 \\
\hline Aldosterone blockers & 13.1 & 18.6 & $<0.0001$ & 12.1 & 14.2 & $<0.0001$ \\
\hline ACE inhibitors & 22.1 & 12.7 & $<0.0001$ & 24.9 & 20.0 & $<0.0001$ \\
\hline$\alpha \beta$-blockers & 6.5 & 14.0 & $<0.0001$ & 10.2 & 12.8 & $<0.0001$ \\
\hline Non-thiazides & 14.3 & 11.9 & 0.02 & 8.1 & 9.8 & $<0.0001$ \\
\hline$\beta$-blockers & 10.2 & 10.7 & 0.6 & 9.3 & 10.4 & 0.02 \\
\hline Thiazides & 9.4 & 9.2 & 0.8 & 9.6 & 12.9 & $<0.0001$ \\
\hline$\alpha$-blockers & 9.7 & 7.9 & 0.03 & 11.1 & 7.4 & $<0.0001$ \\
\hline Direct renin & & & & & & \\
\hline inhibitors & 0.0 & 3.5 & $<0.0001$ & 0.0 & 2.4 & NA \\
\hline Others & 2.4 & 2.7 & 0.6 & 2.4 & 2.3 & $>0.9$ \\
\hline No. of antihypertensive drugs $\geq 3$ & 29.0 & 30.0 & 0.4 & 32.3 & 35.7 & $<0.0001$ \\
\hline
\end{tabular}

Prescription rates for each year. Thiazides include indapamide, which is a thiazide-related diuretic. Non-thiazides did not include aldosterone blockers. ACE: angiotensin converting enzyme, ARBs: angiotensin II receptor blockers, CCBs: calcium channel blockers. The chi-square test or the McNemar test was used for analyses. NA: not applicable because of no observation in 2009.

ウム拮抗薬および ARBsであり，2014 年でそれ ぞれ $65.2 \% ， 59.9 \%$ あった．各降圧薬の処方割 合は，カルシウム拮抗薬，ARBs，非サイアザイ ド系利尿薬， $\beta$ 遮断薬，サイアザイド系（類似） 利尿薬，拈よびその他の降圧薬では 2009 年と 2014年で処方割合に有意な差はなかった $(P>0.07)$. 一方，アルドステロン拮抗薬， $\alpha \beta$ 遮断薬，およ び直接的レニン阻害薬は 2009 年と比較して 2014 年で処方割合が有意に高值であった $(P<0.0001)$. また, ACE 阻害薬および $\alpha$ 遮断薬の処方割合は, 2009 年と比較して 2014 年で処方割合が有意に低 值であった $(P<0.0001)$.

2009 年と 2014 年で重複して含まれる患者 2,020 名とそれ以外で層別解析を行った。非重複群と重 複群の両群のアルドステロン拮抗薬, ACE 阻害 薬, $\alpha \beta$ 遮断薬, $\alpha$ 遮断薬, および直接的レニン 阻害薬の処方割合の変化は, 全体の結果と同様で あった（Table 2)。一方，非重複群では非サイア ザイド系利尿薬の処方割合の有意な低下が認めら れ，重複群ではカルシウム拮抗薬，ARBs，およ び非サイアザイド系・サイアザイド系利尿薬の処 方割合の有意な増加が認められた（Table 2)。服 用降圧薬剂数 3 剂以上の割合は, 重複群でのみ 2014 年で増加していた（Table 2).

降圧薬 1 剤のみ服用している患者の処方割合を 対象としたところ，2009 年 $(n=1,434)$ と 2014 年 （n=1,810）の処方割合はそれぞれ，カルシウム拮 抗薬で $35.4 \%$ vs $37.6 \%(P=0.2)$, ARBs で $40.8 \%$ vs $40.4 \% （ P=0.8)$, アルドステロン拮抗薬で $2.0 \%$ vs $1.7 \%(P=0.6)$, ACE 阻害薬で $9.4 \%$ vs $7.3 \%$ $(P=0.03), \alpha \beta$ 遮断薬で $1.7 \%$ vs $1.6 \% \quad(P=0.8)$, 非サイアザイド系利尿薬で $3.2 \%$ vs $3.3 \%(P=0.9)$, $\beta$ 遮断薬で $4.5 \%$ vs $4.8 \% （ P=0.6)$, サイアザイド 系利尿薬で $0.6 \%$ vs $0.6 \%(P=0.9), \alpha$ 遮断薬で $1.8 \%$ vs $1.0 \%(P=0.045)$, およびその他降圧薬で $0.9 \%$ vs $1.4 \%(P=0.2)$ と, 有意な処方割合の差 異が ACE 阻害薬と $\alpha$ 遮断薬についてのみ認めら れた。

各薬効分類において 2014 年の処方割合が上位 3 位以内であった一般名の処方動向を Table 3 に 示す． 2009 年に比べた 2014 年における有意な処 方割合の増加がアムロジピン, スピロノラクトン, エプレレノン, カルベジロール，ラベタロール， ビソプロロール，およびヒドロクロロチアジドに 認められ，有意な処方割合の減少がカンデサル夕 ン，ロサルタン，エナラプリル，イミダプリル， アロチノロール，アテノロール，ドキサゾシン， およびブナゾシンに認められた（Table 3).

\section{3. 患者特性調整後の各種降圧薬処方オッズ比}

Figure 3 に, 各種降圧薬を目的変数, Table 1 で示した患者特性および 2014 年 = 1（2009 年 = 0) 
Table 3 Drugs with top 3 prescription rates in 2014

\begin{tabular}{|c|c|c|c|c|}
\hline & \multicolumn{4}{|c|}{ Prescription Rate, \% } \\
\hline & Drug name & $\begin{array}{c}2009 \\
(\mathrm{n}=3,954)\end{array}$ & $\begin{array}{c}2014 \\
(\mathrm{n}=5,196)\end{array}$ & $P$ \\
\hline \multirow[t]{3}{*}{ CCBs } & Amlodipine & 25.0 & 30.3 & $<0.0001$ \\
\hline & Nifedipine & 16.1 & 15.6 & 0.6 \\
\hline & Benidipine & 9.3 & 8.4 & 0.1 \\
\hline \multirow[t]{3}{*}{ ARBs } & Candesartan & 16.3 & 13.3 & $<0.0001$ \\
\hline & Olmesartan & 11.5 & 11.5 & 0.9 \\
\hline & Losartan & 10.8 & 8.8 & 0.001 \\
\hline \multirow[t]{3}{*}{ ACE inhibitors } & Enalapril & 9.4 & 6.0 & $<0.0001$ \\
\hline & Imidapril & 5.2 & 3.6 & 0.0004 \\
\hline & Perindopril & 2.7 & 2.9 & 0.7 \\
\hline \multirow[t]{2}{*}{ Aldosterone blockers } & Spironolactone & 8.6 & 11.3 & $<0.0001$ \\
\hline & Eplerenone & 4.0 & 5.6 & 0.0003 \\
\hline \multirow[t]{3}{*}{$\alpha \beta$-blockers } & Carvedilol & 7.5 & 13.2 & $<0.0001$ \\
\hline & Labetalol & 0.1 & 0.3 & 0.003 \\
\hline & Arotinolol & 0.8 & 0.0 & $<0.0001$ \\
\hline \multirow[t]{3}{*}{$\beta$-blockers } & Bisoprolol & 4.1 & 6.7 & $<0.0001$ \\
\hline & Atenolol & 4.0 & 2.8 & 0.0006 \\
\hline & Metoprolol & 0.7 & 0.6 & 0.8 \\
\hline \multirow[t]{3}{*}{$\alpha$-blockers } & Doxazosin & 5.7 & 4.5 & 0.01 \\
\hline & Bunazosin & 3.8 & 2.5 & 0.0006 \\
\hline & Urapidil & 1.0 & 0.6 & 0.08 \\
\hline \multirow[t]{3}{*}{ Diuretics * } & Furosemide & 11.1 & 11.1 & $>0.9$ \\
\hline & Trichlormethiazide & 4.8 & 5.5 & 0.1 \\
\hline & Hydrochlorothiazide & 0.8 & 3.2 & $<0.0001$ \\
\hline
\end{tabular}

The prescription rate was based on the percentage of total patients $(n=3,954$ in 2009, $n=5,196$ in 2014). * Diuretics include all type of diuretics other than aldosterone blockers. ACE: angiotensin converting enzyme, ARBs: angiotensin II receptor blockers, CCBs: calcium channel blockers. We compared proportions using the chi-square test.

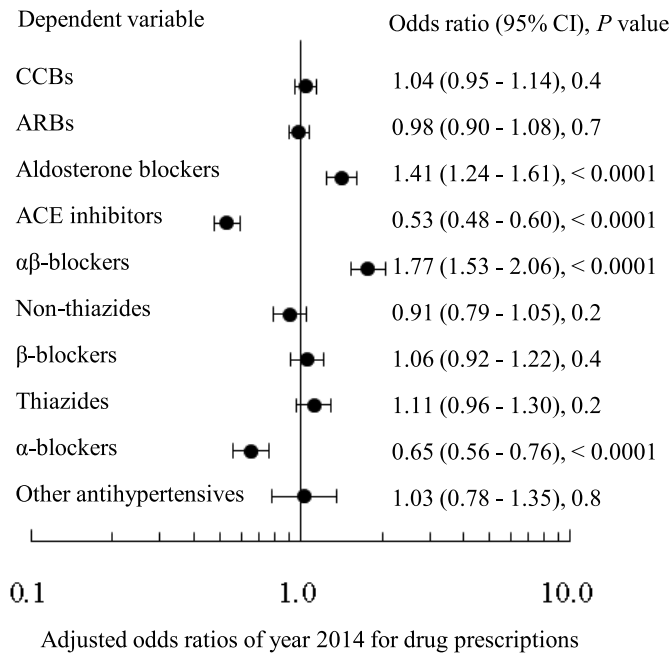

Fig 3 Adjusted odds ratios of year 2014 for each prescription rate

Covariates were sex, age, diabetes, heart failure, ischemic heart disease, cerebrovascular disease, chronic kidney disease, and the number of antihypertensive drugs $\geq 3$. Thiazides include indapamide, which is a thiazide-related diuretic. Non-thiazides did not include aldosterone blockers. Direct renin inhibitors were excluded from the analysis because their prescription rate in 2009 was $0.0 \%$. ACE, angiotensin converting enzyme; ARBs, angiotensin II receptor blockers; CCBs, calcium channel blockers. Multivariate logistic regression analysis was used.
を説明変数とした多重ロジスティック回帰分析の 結果を示す. 各種因子補正後, 2009 年を 1.0 (基準) とした 2014 年のアルドステロン拮抗薬, ACE 阻 害薬, $\alpha \beta$ 遮断薬, および $\alpha$ 遮断薬処方オッズ比は, それぞれ $1.41 ， 0.53 ， 1.77$ ，および 0.65 であった (Fig 3).

\section{考察}

当院における 2009 年および 2014 年の降圧薬の 処方割合は, 1 位がカルシウム拮抗薬, 2 位が ARBs であった. 2005 年時点の 3 大学病院または 2003 年時点の多施設医療機関を対象とした調査で は, カルシウム拮抗薬の処方割合が 6 割であった 一方, ARBs の処方割合は 4 割であった. ${ }^{8,10)} 2005$ 年〜2011 年の健康保険組合のレセプトデータに 基づいて降圧薬の処方推移を検討した調査では, 7 カルシウム拮抗薬（約 $65 \%$ ）が 1 位を維持し, ARBs が継続して 2 位であったが, ARBsの処方 
割合は 2005 年の約 $40 \%$ から 2011 年の約 $60 \%$ へ と増加している。一方, 本研究における ARBsの 2009 年と 2014 年の処方割合は継続して $60 \%$ 前後 であったことより，ARBsの近年の処方割合は変 化していないことが示唆された.

2009 年に比べ，2014 年でアルドステロン拮抗薬 の処方割合が増加, ACE 阻害薬の処方割合が減少 していた.アルドステロン拮抗薬は, 原発性アル ドステロン症やアルドステロン過剩分泌が本態性 高血圧の一因として明らかにされて以降, ${ }^{1,11,12)}$ 有 用な降圧薬として注目されている. 1,13) 過去に我々 は日本人に打けるエプレレノンの降圧効果を立証 しており, ${ }^{14)}$ アルドステロン拮抗薬の処方割合の 増加にはこれらのエビデンスの蓄積が影響してい る可能性がある。 ACE 阻害薬と ARBs は共に, レニンーアンジオテンシンーアルドステロン系 （renin-angiotensin-aldosterone system: RAAS）阻害 により降圧作用をもたらす薬剤であるが，ACE 阻害薬は空咳副作用を有するという弱みがある. ${ }^{1)}$ また, 近年では新規 ARBs のアジルサルタン（販 売開始 : 20/40 mg 錠 2012 年 5 月, $10 \mathrm{mg}$ 錠 2014 年 6 月）とイルベサルタン（販売開始：50/100 $\mathrm{mg}$ 錠 2008 年 7 月, $200 \mathrm{mg}$ 錠 2013 年 6 月) の発売, 前述のアルドステロン拮抗薬に関するエビデンス の蓄積, および直接的レニン阻害薬の登場（販売 開始：2009 年 10 月）が影響し, ACE 阻害薬に対 する関心が低下した可能性が考えられる. 加えて, 以前注目されていた ARBs と ACE 阻害薬の併用 が腎障害をもたらす可能性が，糖尿病を対象とし た Ongoing Telmisartan Alone and in combination with Ramipril Global Endopoint Trial (ONTARGET) などで示されている. ${ }^{15,16)} 2014$ 年 6 月には, 日本 の医薬品医療機器総合機構から ARBs と ACE 阻 害薬の併用について注意喚起がなされており (http://www.pmda.go.jp/safety/info-services/drugs/ calling-attention/revision-of-precautions/0266.html, 2016 年 6 月 23 日), これらが ACE 阻害薬の処方 減少を後押しした可能性がある。

$\beta$ 遮断薬の処方割合に変化は認められなかった (Fig 2).ここの結果は, 第一選択薬のみを服用し ている可能性が高い降圧薬 1 郕のみ服用の患者を 対象とした場合，並びに交絡要因と考えられる患
者特性で補正した場合も同様であった（Fig 3). JSH ガイドライン 2014 では, $\beta$ 遮断薬は高血圧 治療の第一選択薬から除外されたが, 交感神経系 の抑制, 心筋梗塞の再発防止, または心不全の予 後改善効果に関する $\beta$ 遮断薬の有用性について は継続して言及されており, ${ }^{1)}$ 合併症を有する患 者が比較的多い当院においてはJSH ガイドライ ン改定が及ぼす $\beta$ 遮断薬処方への影響は少なかっ た可能性がある。ただし, 本研究の調査期間は 2014 年では 4 7 月末までと JSH ガイドライン 2014 が発表された直後である.ガイドラインの 内容がより一般化する数年後では, 異なる知見が 得られる可能性が考えられる。

$\beta$ 遮断薬と同様の交感神経抑制薬である $\alpha$ 遮断 薬の処方割合の減少が認められたが, これは起立 性低血圧副作用への懸念が影響した可能性が考え られる，他方で, $\alpha \beta$ 遮断薬, 特にカルベジロー ルの処方割合が増加している（Table 3). カルベ ジロールは 8:1の比率で $\beta$ 遮断作用に比べて $\alpha$ 遮断作用が弱いため, 起立性低血圧なしに末梢血 管抵抗を抑えられると考えられている. ${ }^{17)}$ さらに, カルベジロールは慢性心不全の進展抑制も期待さ れており, 本研究の結果は $\alpha \beta$ 遮断薬の関心が高 まっていることを反映した可能性がある.

2009 年と 2014 年で重複して含まれる患者とそ れ以外で層別解析を行った結果でも, アルドステ ロン拮抗薬, $\alpha \beta$ 遮断薬, ACE 阻害薬, $\alpha$ 遮断薬 の有意な処方割合の変化に差は認められなかっ た。一方で, 非サイアザイド系利尿薬は, 非重複 群でのみ処方割合が低下していた（Table 2). 非 重複群では降圧薬 3 郕以上の割合が 2009 年と 2014 年で差がないため, 非サイアザイド系利尿 薬の代わりに処方割合が増加したアルドステロン 拮抗薬や直接的レニン阻害薬などが処方されてい る可能性が考えられる。 また, 重複群では, $\beta$ 遮 断薬の有意な増加が認められている（Table 2). しかし, これは, 全体では差が認められなかった ほかの降圧薬の処方割合が増加していたことよ り, 服用降圧薬剂数の増加それ自体が影響した可 能性が考えられる。

本研究では幾つかの研究限界が存在する。第一 に, 本研究では, 用量, 用法, 薬価, さらに後発 
品に関する情報を考慮していない．これらを検討 に加えることで，より詳細な降圧薬処方推移を把 握することが可能と考えられる．特に後発医薬品 について, 後発医薬品を推奨する薬剤師の増加や, 2012 年以降の一般名処方の増加が報告されてい る. ${ }^{18)}$ 患者希望などを含め, 後発医薬品の数や薬 価が処方割合に影響している可能性を否定できな い. しかし， 2009 年以前に後発品が発売されて いるエナラプリルの処方割合は減少，現在も後発 品がないエプレレノンの処方割合は増加，という 本研究の結果から, 後発医薬品の影響を超えた処 方割合の変遷があったと考えられる．第二に， 1 剤のみ服用している患者の処方割合から第一選択 薬の処方割合の変化を推定した。しかし，調查期 間以前で他院から降圧薬を処方されていた可能性 や，デー夕抽出期間以前から降圧薬を服用してい た可能性があるため，必ずしも 1 剂のみ服用の患 者が第一選択薬の降圧薬を服用していたとは限ら ない. 第一選択薬の処方割合の推移を明らかにす るためには, 調査期間内に降圧薬治療を新規に開 始した患者を対象とする必要がある，第三に，既 往歴が傷病名により定義されているため, 保険傷 病名の影響によりその割合が過大評価されている 可能性がある。また，既往歴として定義している ため, 調查時点では寛解した疾患が含まれている 可能性がある. 検查值, 治療薬, およびその他医 療行為などの客観的な情報を用いることで，傷病 名によって定義された各既往歴の妥当性について 検証する必要がある。第四に, 観察期間内に降圧 薬が異なる降圧薬へ切り替えとなった場合は両者 が処方ありと計算される点である。しかし，降圧 薬は長期に安定した処方内容となる場合が多く, また観察期間を各年 4 カ月間としていることよ り，この影響は限定的であったと考えられる．最 後に, 単一の大学病院での結果であり, 外的妥当 性が限られる，採用薬の影響や，比較的重症の対 象者が選ばれている可能性があるため，他機関に おける再現性の確認が必要である。一方で，単一 機関であっても処方割合の動向を捉えられたこと の意義は大きいと考えられる，厚生労働省からナ ショナルレセプトデータの利用なども推進されて いるが, 複数の機関から得られた膨大なデータで
ある. 要求されるセキュリティやコンピューター 処理能力の制限から, 施設によってはその利用自 体が難しいことも考えられているため, ${ }^{19}$ 本研究 のような試みが迅速なエビデンスの構築に貢献す ると考えられる。

結論として, 当院のレセプトデータを用いた調 査で, 高血圧患者に対する降圧薬のうち, カルシ ウム拮抗薬ならびに ARBs が継続して高率に処方 されている実態が示された。一方，2009年と比 較して，2014 年でアルドステロン拮抗薬，およ び $\alpha \beta$ 遮断薬の処方割合が増加, ACE 阻害薬㧍よ び $\alpha$ 遮断薬の処方割合が減少していたが， $\beta$ 遮断 薬を含むその他の降圧薬の処方割合に有意な変化 は認められなかった。これらの変遷には, 高血圧 病態や副作用に関する新たなエビデンスが影響し ていると考えられる.

\section{謝 辞}

本研究のデー夕収集・解析を行うにあたり，ご 尽力賜りました当院のスタッフの方々に感謝申し 上げます。本研究は, 文部科学省研究費助成事業 特別研究員奨励費（25・9328）の一環として実 施された。

\section{利益相反}

開示すべき利益相反はない.

\section{引用文献}

1) Shimamoto K, Ando K, Fujita T, Hasebe N, Higaki J, Horiuchi M, Imai Y, Imaizumi T, Ishimitsu T, Ito M, Ito $\mathrm{S}$, Itoh $\mathrm{H}$, Iwao $\mathrm{H}$, Kai H, Kario K, Kashihara N, Kawano Y, Kim-Mitsuyama S, Kimura G, Kohara K, Komuro I, Kumagai H, Matsuura H, Miura K, Morishita R, Naruse M, Node K, Ohya Y, Rakugi H, Saito I, Saitoh S, Shimada K, Shimosawa T, Suzuki H, Tamura K, Tanahashi N, Tsuchihashi T, Uchiyama M, Ueda S, Umemura S, Japanese Society of Hypertension Committee for Guidelines for the Management of Hypertension, The Japanese Society of Hypertension Guidelines for the Management of 
Hypertension (JSH 2014), Hypertens Res, 2014, 37, 253-387.

2) Miura K, Nagai M, Ohkubo T, Epidemiology of hypertension in Japan: where are we now? Circ J, 2013, 77, 2226-2231.

3) Elliott WJ, Meyer PM, Incident diabetes in clinical trials of antihypertensive drugs: a network metaanalysis, Lancet, 2007, 369, 201-207.

4) Mancia G, Grassi G, Zanchetti A, New-onset diabetes and antihypertensive drugs, J Hypertens, 2006, 24, 3-10.

5) Klingbeil AU, Schneider M, Martus P, Messerli FH, Schmieder RE, A meta-analysis of the effects of treatment on left ventricular mass in essential hypertension, Am J Med, 2003, 115, 41-46.

6) Lindholm LH, Carlberg B, Samuelsson O, Should beta blockers remain first choice in the treatment of primary hypertension? A meta-analysis, Lancet, 2005, 366, 1545-1553.

7) Kohro T, Yamazaki T, Sato H, Ohe K, Nagai R, The impact of a change in hypertension management guidelines on diuretic use in Japan: trends in antihypertensive drug prescriptions from 2005 to 2011, Hypertens Res, 2013, 36, 559-563.

8) Kamijima Y, Ooba N, Yagame M, Samizo K, Shimodozono Y, Kageyama S, Horiguchi S, Nagai R, Kusunoki T, Kubota K, Hypertension management in diabetic patients: prescribing trends from 1999 to 2005 in three Japanese university hospitals, Pharmacoepidemiol Drug Saf, 2008, 17, 904-911.

9) Satoh M, Obara T, Nishigori H, Ooba N, Morikawa Y, Ishikuro M, Metoki H, Kikuya M, Mano N, Prescription trends in children with pervasive developmental disorders (PDD): A claims data-based study in Japan, World J Pediatr, 2016, 12, 443-449.

10) Obara $T$, Ohkubo $T$, Kikuya M, Asayama K, Metoki H, Inoue R, Oikawa T, Murai K, Komai R, Horikawa T, Hashimoto J, Totsune K, Imai Y, Group JHS, The current status of home and office blood pressure control among hypertensive patients with diabetes mellitus: the Japan Home Versus Office Blood Pressure Measurement Evaluation (J-HOME) study, Diabetes Res Clin Pract, 2006, 73, 276-283.

11) Satoh M, Kikuya M, Hara A, Ohkubo T, Mori T, Metoki H, Utsugi MT, Hirose T, Obara T, Inoue R, Asayama K, Totsune K, Hoshi H, Satoh H, Imai Y, Aldosterone-to-renin ratio and home blood pressure in subjects with higher and lower sodium intake: the
Ohasama study, Hypertens Res, 2011, 34, 361-366.

12) Satoh M, Kikuya M, Ohkubo T, Mori T, Metoki H, Hara A, Utsugi MT, Hashimoto T, Hirose T, Obara T, Inoue R, Asayama K, Kanno A, Totsune K, Hoshi H, Satoh H, Imai Y, Aldosterone-to-renin ratio as a predictor of stroke under conditions of high sodium intake: the Ohasama study, Am J Hypertens, 2012, 25, 777-783.

13) Colussi G, Catena C, Sechi LA, Spironolactone, eplerenone and the new aldosterone blockers in endocrine and primary hypertension, J Hypertens, 2013, 31, 3-15.

14) Elnagar N, Satoh M, Hosaka M, Asayama K, Ishikura K, Obara T, Mano N, Ohkubo T, Imai Y, The velocity of home blood pressure reduction in response to low-dose eplerenone combined with other antihypertensive drugs determined by exponential decay function analysis, Clin Exp Hypertens, 2014, 36, 83-91.

15) Mann JF, Schmieder RE, McQueen M, Dyal L, Schumacher H, Pogue J, Wang X, Maggioni A, Budaj A, Chaithiraphan S, Dickstein K, Keltai M, Metsarinne K, Oto A, Parkhomenko A, Piegas LS, Svendsen TL, Teo KK, Yusuf S, investigators O, Renal outcomes with telmisartan, ramipril, or both, in people at high vascular risk (the ONTARGET study): a multicentre, randomised, double-blind, controlled trial, Lancet, 2008, 372, 547-553.

16) Makani H, Bangalore S, Desouza KA, Shah A, Messerli FH, Efficacy and safety of dual blockade of the renin-angiotensin system: meta-analysis of randomised trials, BMJ, 2013, 346, f360.

17) Clifton JE, Collins I, Hallett P, Hartley D, Lunts LH, Wicks PD, Arylethanolamines derived from salicylamide with alpha- and beta-adrenoceptor blocking activities. Preparation of labetalol, its enantiomers, and related salicylamides, J Med Chem, 1982, 25, 670-679.

18）高橋則男, 小原 拓, 猪狩有紀恵, 高橋 武, 東二丁裕子, 遠藤 孝, 眞野成康, 早坂正孝, 高橋 將喜, 鎌田 裕, 北村哲司, 後発医薬品に関する 薬剂師の認識：社団法人仙台市薬剂師会, 医薬 品相互作用研究, 2013, 36, 168-172.

19）三浦克之, 宮川尚子, 村上義孝, 角野文彦, 岡山 明, レセプト情報・特定健診等情報データベー スの概要と活用の方向性一滋賀県特定健診デー 夕分析事例から一, 保健医療科学, 2013, 62, 3135. 